\title{
A Concrete Model Considering the Load History Applied to Centrally Loaded Columns Under Fire Attack
}

\author{
ULRICH SCHNEIDER, Univ. Prof. Dr. and TAKESHI MORITA, Research Fellow \\ Institute of Building Materials, Building Physics and Fire Protection \\ Technical University of Vienna \\ Karlsplatz 13/206, A-1040 Vienne. Austria
}

\section{JEAN-MARC FRANSSEN}

Research Associate of the National Fund for Scientific Research

University of Liège

6. Quai Banning

B-4000, Liège, Belgium

\begin{abstract}
.
The description is given of a model for concrete in compression at elevated temperature that incorporates elastic, plastic and creep strains as functions of the temperature and stress history. The plastic strain and the creep strain depend on the stress history and the stiffness of the model depends on the load level during fire exposure. The proposed model is an updated version of a model presented earlier by one of the author [1].
\end{abstract}

Fifteen fire resistance tests have been performed on reinforced concrete columns centrally loaded under various heating, loading and restraint conditions. From the test results, it can be concluded that the strength of columns during fire is irrelevant to the restraint of elongation, and that the sustained load about 0.15 load level leads to a higher residual strength than the unloaded condition does.

A comparison is given between experimental results and computed results. The calculations were performed either with the proposed Schneider concrete model or with the EC4 concrete model. The proposed model is closer to experimental values than the EC4 model when considering longitudinal displacements as well as axial restraint forces.

Keywords : Concrete, material model, fire, elevated temperature, thermal analysis, creep, plasticity, cooling down, column, test, residual strength, calculation, Eurocode. 


\section{INTRODUCTION.}

The load level existing in concrete during the heating is known to have an influence on the behaviour of concrete elements at elevated temperature, especially on its stiffness. The higher the load level during the heating up, the stiffer the material. This phenomena, as well as the influence of creep on the deformation of concrete under fire, had been introduced in a theoretical model proposed earlier by Schneider[1]. The concrete model proposed in Eurocode 4 [2] is based on the Schneider model, from which some basic equations have been taken, but the effect of the load history and of concrete transient creep have not been considered.

Franssen and Schneider have recently updated the model proposed in [1], and Franssen has introduced it in the code SAFIR which is being developed at the university of Liège [3]. While spending a year in Vienna, Morita has also incorporated this updated version of the Schneider model in the code Fires - Frame I developed at Chiba University [4,5].

The results of the simulations made by both codes, each with the two concrete models mentioned above have been compared to the results of experimental fire tests made in Japan on centrally loaded concrete columns in order to inspect the material behaviour in fire and the residual mechanical properties.

\section{THE CONCRETE MODEL.}

\section{Basic equation.}

$$
\begin{aligned}
& \varepsilon_{\text {tot }}=\varepsilon_{\mathrm{e}}+\varepsilon_{\mathrm{pl}}+\varepsilon_{\mathrm{cr}}+\varepsilon_{\mathrm{th}} \\
& \text { where } \varepsilon_{\text {tot }}: \text { total strain, } \\
& \varepsilon_{\mathrm{e}} \quad: \quad \text { elastic strain, } \\
& \varepsilon_{\mathrm{pl}}: \quad \text { plastic strain, } \\
& \varepsilon_{\text {cr }} \quad: \quad \text { creep strain, } \\
& \varepsilon_{\text {th }}: \quad \text { thermal strain, }
\end{aligned}
$$

\section{Total strain.}

The total strain is the one that is derived from the field of displacements. It is indeed the value that is introduced as an input in the model and which will be used (with the temperature) to calculate the stress and the tangent modulus. The model can be applied whatever the expression that is used to derive the total strain, linear or non linear expression for example.

\section{Thermal strain.}

The thermal strain in this model is, for gravel concrete;

$$
\begin{array}{ll}
\varepsilon_{t h}=-1.8 \times 10^{-4}+9 \times 10^{-6} \times T+2.3 \times 10^{-11} \times T^{3} & \left(T \leq 700^{\circ} \mathrm{C}\right) \\
\varepsilon_{t h}=1.4 \times 10^{-3} & \left(700^{\circ} \mathrm{C}<T\right)
\end{array}
$$

It is assumed that shrinkage is accounted for by the thermal strain as this one is usually determined by testing unsealed (i. e. drying ) concrete specimen. 


$$
\sigma=f c \times \frac{\varepsilon_{s}}{\varepsilon_{u}} \times \frac{n}{(n-1)+\left(\frac{\varepsilon_{s}}{\varepsilon_{u}}\right)^{n}}
$$

where $\sigma \quad$ : $\quad$ stress,

$$
\begin{array}{lll}
f_{\mathrm{c}} & : & \text { strength at high temperature, } \\
\varepsilon_{\mathrm{S}} & : & \text { stress strain }\left(=\varepsilon_{\mathrm{e}}+\varepsilon_{\mathrm{pl}}\right),
\end{array}
$$$$
\varepsilon_{\mathrm{u}} \quad \text { : } \quad \text { strain corresponding to } \mathrm{f}_{\mathrm{c}} \text { and load history, }
$$

$\mathrm{n}: \quad=3$ for normal concrete, $=2.5$ for light weight concrete.

\section{Elastic strain.}

$\varepsilon_{e}=\frac{\sigma}{E}$

where $\mathrm{E}$

modulus of elasticity.

The general equation for modulus of elasticity is;

$E=\left.\frac{\partial \sigma}{\partial \varepsilon_{\sigma}}\right|_{\varepsilon_{\sigma-0}}=1.5 \times \frac{f_{c}}{\varepsilon_{u}}$

Note : As $\varepsilon_{\mathrm{u}}$ depends on the load history ( see Eq. 8 ), the modulus of elasticity is temperature and load dependent.

The evolution of $f_{c}$ as a function of temperature is;

$\mathrm{f}_{\mathrm{c}}=\mathrm{f}_{\mathrm{c}}\left(20^{\circ} \mathrm{C}\right)$

$\left(\mathrm{T} \leq 250^{\circ} \mathrm{C}\right)$

$\mathrm{f}_{\mathrm{C}}=\mathrm{f}_{\mathrm{C}}\left(20^{\circ} \mathrm{C}\right) \times[1-0.0018(\mathrm{~T}-250)]$

$\left(250^{\circ} \mathrm{C}<\mathrm{T} \leq 750^{\circ} \mathrm{C}\right)$

$f_{c}=f_{c}\left(20^{\circ} \mathrm{C}\right) \times[0.1-0.0004(T-750)]$

$\left(750^{\circ} \mathrm{C}<\mathrm{T} \leq 1000^{\circ} \mathrm{C}\right)$

$\mathrm{f}_{\mathrm{c}}=0$

$\left(1000^{\circ} \mathrm{C}<\mathrm{T}\right)$

One of the original aspects of this model is that $\varepsilon_{\mathrm{u}}$ depends on the load level present in the concrete prior to the heating. The following expression has been derived from experimental results reported in [6];

$$
\varepsilon_{\mathrm{u}}=\varepsilon_{\mathrm{u}}\left(20^{\circ} \mathrm{C}\right)+\Delta \varepsilon_{\mathrm{u}}(\mathrm{T}) \times \mathrm{f}(\alpha)
$$

where $\varepsilon_{\mathrm{u}}\left(20^{\circ} \mathrm{C}\right)=2.210^{-3}$

$$
\begin{array}{rlrl}
\Delta \varepsilon_{\mathrm{u}}(\mathrm{T}) & =\left[4.2 \times 10^{-6}+(\mathrm{T}-20) \times 5.4 \times 10^{-9}\right](\mathrm{T}-20) & \leq 7.810^{-3} \\
\mathrm{f}(\alpha) & =1 & & (\alpha=0) \\
& =0.227 & & (\alpha=0.1) \\
& =-0.095 & & (\alpha=0.3)
\end{array}
$$

A linear interpolation may be applied for intermediate values of $\alpha$ $\alpha=\frac{\sigma_{\text {hist }}}{f_{c}\left(20^{\circ} \mathrm{C}\right)} \leq 0,3 \quad$ Upper limit to be used irrespective of the actual stress level.

$\sigma_{\text {hist }}$ is a stress level representing the stress history ( for simplification, $\sigma_{\text {hist }}$ has been taken as the stress present in concrete when the heating begins in the calculations discussed in the subsequent part ) 


\section{Plastic strain.}

The plastic strain can be derived from the strain according to Eq. 4. minus the actual elastic strain calculated from Eq. 5. A numerical approximation for the ascending branch of the stress - strain relationship is

$\varepsilon_{p t}=\kappa \times \frac{\sigma}{E}$

where $\kappa=\frac{1}{2}\left\{1-\sqrt{1-\left(\sigma / f_{c}\right)^{4}}\right\}$

\section{Creep strain.}

$\varepsilon_{c r}=\frac{\sigma \times \Phi}{E}$

where $\Phi=\mathrm{g}(\phi+1)-1$ is a temperature and load history dependent transient creep function $\phi=\mathrm{C}_{1} \tanh \gamma_{\mathrm{W}}(\mathrm{T}-20)+\mathrm{C}_{2} \tanh \gamma_{\mathrm{o}}\left(\mathrm{T}-\mathrm{T}_{\mathrm{g}}\right)+\mathrm{C}_{3}$

$\mathrm{C}_{1}, \mathrm{C}_{2}, \mathrm{C}_{3}, \gamma_{\mathrm{o}}$ and $\mathrm{T}_{\mathrm{g}}$ are in table 1 .

$\gamma_{\mathrm{w}}=0.3 \mathrm{w}+2.2 \times 10^{-3}, \mathrm{w}=$ moisture content in $\%$ by weight.

$g=1+0.7 \alpha(0.6-\alpha)\left(\frac{T-20}{100}\right)^{2}$

$\mathrm{g}(\alpha, \mathrm{T})$ is the function allowing for the increase of elasticity due to external loads. It has been derived from experimental results, i.e. $\mathrm{E}(\alpha, \mathrm{T})$ is a function of the load level during the heating up [7]. This is already taken into account by using Eq. 6 .

TABLE 1. Parameters for transient creep functions $\phi$ of structural concrete.

\begin{tabular}{|c|c|c|c|c|}
\hline Parameter & Dimension & $\begin{array}{c}\text { Quartzite } \\
\text { concrete }\end{array}$ & $\begin{array}{c}\text { Limestone } \\
\text { concrete }\end{array}$ & $\begin{array}{c}\text { Lightweight } \\
\text { concrete }\end{array}$ \\
\hline $\mathrm{C}_{1}$ & 1 & 2.60 & 2.60 & 2.60 \\
\hline $\mathrm{C}_{2}$ & 1 & 1.40 & 2.40 & 3.00 \\
\hline $\mathrm{C}_{3}$ & 1 & 1.40 & 2.40 & 3.00 \\
\hline$\gamma_{0}$ & ${ }^{\circ} \mathrm{C}^{-1}$ & $7.5 \times 10^{-3}$ & $7.5 \times 10^{-3}$ & $7.5 \times 10^{-3}$ \\
\hline $\mathrm{T}_{\mathrm{g}}$ & $\mathrm{C}$ & 700 & 650 & 600 \\
\hline
\end{tabular}

\section{Scheme of resolution.}

The ordinary procedure in most displacement based structural programs is to calculate $\sigma$ as a function of $\varepsilon_{\mathrm{m}}$. As this model is written in the form $\varepsilon_{\mathrm{m}}=\mathrm{f}(\sigma, \mathrm{T})$, an iteration process is necessary to find $\sigma\left(\varepsilon_{\mathrm{m}}\right)$ which satisfies Eq. 2 . The classical Newton approach is used.

$$
\sigma_{n+1}=\sigma_{n}+\frac{\varepsilon_{m}-\varepsilon_{m}\left(\sigma_{n}\right)}{\left.\frac{\partial \varepsilon_{m}}{\partial \sigma}\right|_{\varepsilon_{m}\left(\sigma_{n}\right)}}
$$

where

$$
\begin{array}{lll}
\sigma_{\mathrm{n}} & : & \text { stress at iteration } \mathrm{n} \\
\sigma_{\mathrm{n}+1} & : & \text { stress at iteration } \mathrm{n}+1
\end{array}
$$


The derivative of $\varepsilon_{m}$ appears in Eq.13 and some decisions must be taken concerning the behaviour of the model when the strain decreases.

\section{Elastic strain.}

In any case, we have;

$\varepsilon_{e}=\frac{\sigma}{E\left(\sigma_{\text {hist }}, T\right)}, \quad$ and $\quad \frac{\partial \varepsilon_{e}}{\partial \sigma}=\frac{1}{E\left(\sigma_{\text {hist }}, T\right)}$

\section{Plastic strain.}

Let us note $\quad \varepsilon_{\mathrm{pl}}^{\mathrm{n}-1} \quad$ : the plastic strain in the material at the end of the time step n-1, i.e. when convergence had been obtained,

$$
\varepsilon_{p l}^{*}=\frac{\sigma}{E\left(\sigma_{\text {hist }}, T\right)} \times \kappa(T)
$$

If $\quad \varepsilon_{\mathrm{pl}}^{*}>\varepsilon_{\mathrm{pl}}^{\mathrm{n}-1}$

then $\quad \varepsilon_{\mathrm{pl}}=\varepsilon_{\mathrm{pl}}^{*} \quad$ and $\frac{\partial \varepsilon_{p l}}{\partial \sigma}=\frac{\kappa(T)}{E\left(\sigma_{\text {hist }}, T\right)}+\frac{\sigma}{E\left(\sigma_{\text {hist }}, T\right)} \times \frac{\partial \kappa(T)}{\partial \sigma}$

else $\quad \varepsilon_{\mathrm{pl}}=\varepsilon_{\mathrm{pl}}^{\mathrm{n}-1} \quad$ and $\quad \frac{\partial \varepsilon_{\mathrm{pl}}}{\partial \sigma}=0$

Eq. 15 shows that the plastic strain cannot decrease.

\section{Creep strain.}

Let us note $\quad \Delta \varepsilon_{c r}=\frac{\sigma \times \Phi\left(\sigma_{\text {hist }}, T\right)}{E\left(\sigma_{\text {hist }}, T\right)}-\frac{\sigma^{n-1} \times \Phi\left(\sigma_{\text {hist }}, T^{n-1}\right)}{E\left(\sigma_{\text {hist }}, T^{n-1}\right)}$

If $\Delta \varepsilon_{\mathrm{cr}}>0$

then $\quad \varepsilon_{\mathrm{cr}}=\varepsilon_{\mathrm{cr}}^{\mathrm{n}-1}+\Delta \varepsilon_{\mathrm{cr}} \quad$ and $\quad \frac{\partial \varepsilon_{\mathrm{cr}}}{\partial \sigma}=\frac{\Phi\left(\sigma_{\text {hist }}, T\right)}{E\left(\sigma_{\text {hist }}, T\right)}$

else $\quad \varepsilon_{\mathrm{cr}}=\varepsilon_{\mathrm{cr}}^{\mathrm{n}-1} \quad$ and $\quad \frac{\partial \varepsilon_{\mathrm{cr}}}{\partial \sigma}=0$

Eq. 16 shows that there is no creep recovery in the proposed model.

Fig. 1 shows how the components of the mechanical strain behave at constant temperature and Fig. 2 shows the evolution in the stress - mechanical strain diagram when the load is applied (three different curves are for three different load levels), the material is heated under constant load and an unloading reloading is done at elevated temperature (plastic strain is small for those load levels).

The concrete model for tensile stress is assumed as one tenth of a stress - strain curve for compression, including no load history and no creep. 


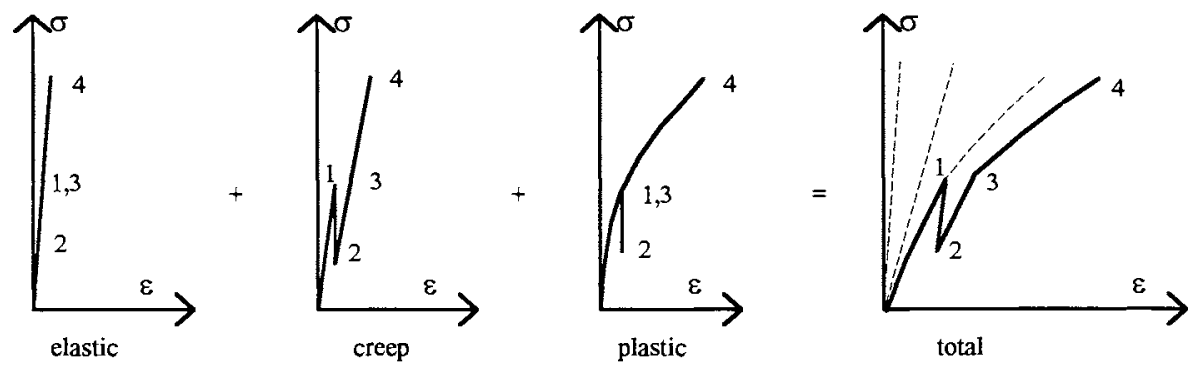

FIGURE 1. Different component of the mechanical strain at constant temperature.

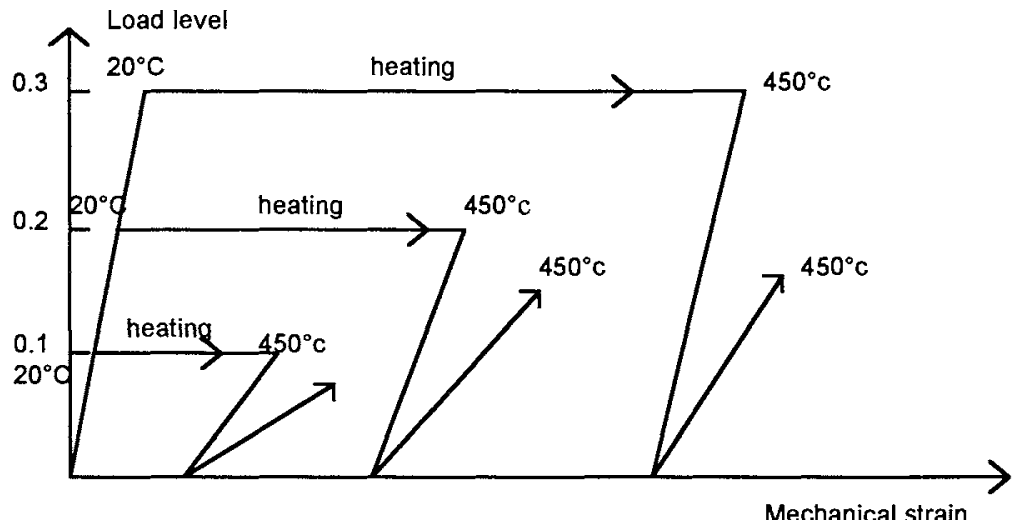

FIGURE 2. Loading - heating - unloading - reheating.

\section{THE TESTS.}

The columns are 300 by $300 \mathrm{~mm}^{2}$ in cross section. Four $16 \mathrm{~mm}$ longitudinal rebars are present with a cover of $40 \mathrm{~mm}$. Each specimen has a centre hole of $100 \mathrm{~mm}$ diameter for loading, and the height of the specimens are limited to $1200 \mathrm{~mm}$, because the accepted ratio $=$ column height / column depth of reinforced concrete columns is approximately between 3.0 and 5.0 in Japan due to earthquakes and wind etc. The ratio of the specimens is $4.0(\mathrm{H}: 1,200$ $\mathrm{mm}$ and $\mathrm{D}: 300 \mathrm{~mm}$ ). The ratio used for the analyses of the test results is 3.0 in order to consider a effective heating surface $(\mathrm{H}: 900 \mathrm{~mm}$ and $\mathrm{D}: 300 \mathrm{~mm})$ during the fire test. Bending and shearing forces are not considered here. The concrete properties are shown in Table 2 and 3 , and the properties of reinforcing steel are shown in Table 4. 
TABLE 2. Mix proportion of concrete $\left(\mathrm{kg} / \mathrm{m}^{3}\right)$

\begin{tabular}{|c|c|c|c|c|c|}
\hline $\begin{array}{c}\text { Portland } \\
\text { cement }\end{array}$ & Water & Sand & Gravel & Plasticizer & Silica \\
\hline 500 & 175 & 673 & 1067 & 8.0 & 0.0 \\
\hline
\end{tabular}

TABLE 3. Properties of hardened concrete

\begin{tabular}{|c|c|c|c|c|}
\hline $\begin{array}{c}\text { Cylinder } \\
\text { strength } \\
\left(\mathrm{N} / \mathrm{mm}^{2}\right)\end{array}$ & $\begin{array}{c}\text { Elastic } \\
\text { modulus } \\
\left(10^{4 *} \mathrm{~N} / \mathrm{mm}^{2}\right)\end{array}$ & $\begin{array}{c}\text { Poisson's } \\
\text { ratio }\end{array}$ & $\begin{array}{c}\text { Bulk } \\
\text { density } \\
\left(\mathrm{kg} / \mathrm{dm}^{3}\right)\end{array}$ & $\begin{array}{c}\text { Moisture content } \\
(\%)\end{array}$ \\
\hline $54.3-59.9$ & $3.34-3.70$ & $0.18-0.24$ & $2.38-2.39$ & $4.2-4.7$ \\
\hline
\end{tabular}

TABLE 4. Properties of reinforcement (Deformed bar)

\begin{tabular}{|c|c|c|c|c|c|}
\hline $\begin{array}{c}\text { Kind of } \\
\text { reinforcement }\end{array}$ & $\begin{array}{c}\text { Cross } \\
\text { section } \\
\left(\mathrm{mm}^{2}\right)\end{array}$ & $\begin{array}{c}\text { Yield stress } \\
\left(\mathrm{N} / \mathrm{mm}^{2}\right)\end{array}$ & $\begin{array}{c}\text { Tensile } \\
\text { strength } \\
\left(\mathrm{N} / \mathrm{mm}^{2}\right)\end{array}$ & $\begin{array}{c}\text { Elastic } \\
\text { modulus } \\
\left(* 10^{5} \mathrm{~N} / \mathrm{mm}^{2}\right)\end{array}$ & $\begin{array}{c}\text { elongation } \\
(\%)\end{array}$ \\
\hline Main & 198 & 375.9 & 559.0 & 2.08 & 26.7 \\
\hline Hoop & 32 & 378.1 & 492.5 & not measured & 30.0 \\
\hline
\end{tabular}

The specimens centrally loaded were exposed to Japanese standard fire temperature - time curve [8] or a reduced fire temperature - time curve. Every fire test was carried out after 3 months of placing the concrete. The loading on the specimens was kept up to 2 or 3 hours after fire exposure. Table 5 shows the test conditions.

TABLE 5. Condition of loading and heating

\begin{tabular}{|c|c|c|c|c|}
\hline Test case & Specimen & Load level ${ }^{*}$ & Fire intensity & Restraint \\
\hline \multirow{3}{*}{ Case-A } & A-1 & 0 & standard * $1.0(180 \mathrm{~min})$ & \multirow{3}{*}{ no } \\
\hline & A-2 & 0 & standard * $0.9(180 \mathrm{~min})$ & \\
\hline & A-3 & 0 & standard *0.6 (180 min $)$ & \\
\hline \multirow{5}{*}{ Case-B } & B-1 & 0.15 & \multirow{5}{*}{$\begin{array}{c}\text { standard } \\
\text { (maximum } 180 \mathrm{~min} \text { ) }\end{array}$} & \multirow{5}{*}{ no } \\
\hline & B-2 & 0.15 & & \\
\hline & B-3 & 0.30 & & \\
\hline & B-4 & 0.28 & & \\
\hline & $B-5$ & 0.45 & & \\
\hline \multirow{7}{*}{ Case-C } & $C-1$ & 0.00 & \multirow{6}{*}{$\begin{array}{c}\text { standard } \\
\text { (maximum } 180 \mathrm{~min} \text { ) }\end{array}$} & \multirow{7}{*}{$\begin{array}{c}\text { restraint } \\
\text { of } \\
\text { elongation }\end{array}$} \\
\hline & $\mathrm{C}-2$ & 0.15 & & \\
\hline & C-3 & 0.16 & & \\
\hline & C-4 & 0.16 & & \\
\hline & C-5 & 0.30 & & \\
\hline & C-6 & 0.43 & & \\
\hline & C-7 & 0.31 & standard $(120 \mathrm{~min})$ & \\
\hline
\end{tabular}

Load level $=\frac{\text { (magnitude of load })}{\left(\text { compressive strength of concrete at } 20^{\circ} \mathrm{C}\right) \times(\text { section of specimen })}$ 
The test results are summarised in Table 6. The ultimate strength of columns at elevated temperature is not affected by the restraint conditions ( compare B-4 with C-5, and B-5 with $\mathrm{C}-6$ ). The residual strength of columns is influenced by the sustained loads according to the comparison between A-1, B-2 and C-4. The residual strength seems to be improved by a sustained load level of about 0.15 , which leads to a higher residual strength than unloaded conditions do, while the residual strength of the restrained column $(\mathrm{C}-4, \mathrm{C}-5)$ is less than that of the unrestrained column (B-1, B-2).

TABLE 6. Summary of test results

\begin{tabular}{|c|c|c|c|c|}
\hline Specimen & $\begin{array}{l}\text { Applied Load } \\
(\mathrm{kN})\end{array}$ & $\begin{array}{c}\text { Max. restraint force } \\
{ }_{1} \\
(\mathrm{kN})\end{array}$ & $\begin{array}{l}{ }_{* 2}^{\text {Collapse }} \\
\text { (minute) }\end{array}$ & $\begin{array}{c}\text { Residual strength }{ }^{*}, 3,3 \\
(\mathrm{kN})\end{array}$ \\
\hline $\mathrm{A}-1$ & 0 & - & - & $1324(0.29), 58$ days \\
\hline $\mathrm{A}-2$ & 0 & - & - & $1785(0.39), 57$ days \\
\hline A-3 & 0 & - & - & $\begin{array}{c}>2452(0.53), 57 \text { days }{ }^{* 4} \\
2845(0.62), 99 \text { days }\end{array}$ \\
\hline B-1 & 677 & - & - & $2010(0.44), 24$ days \\
\hline B-2 & 735 & - & - & $2236(0.46), 68.5 \mathrm{hr}$ \\
\hline B-3 & 1353 & - & - & $1402(0.31), 35$ days \\
\hline B-4 & 1373 & - & $180+47$ & - \\
\hline B-5 & 2030 & - & 115 & - \\
\hline $\mathrm{C}-1$ & 0 & $1638(0.35)$ & - & $1500(0.32), 22.0 \mathrm{hr}$ \\
\hline $\mathrm{C}-2$ & 686 & $2128(0.45)$ & - & $1412(0.30), 20.5 \mathrm{hr}$ \\
\hline $\mathrm{C}-3$ & 735 & $1657(0.35)$ & - & $1814(0.38), 20.5 \mathrm{hr}$ \\
\hline C-4 & 735 & $1795(0.38)$ & - & $1794(0.38), 68.5 \mathrm{hr}$ \\
\hline $\mathrm{C}-5$ & 1373 & $2059(0.45)$ & $180+43$ & - \\
\hline C-6 & 2059 & $2167(0.45)$ & 117 & - \\
\hline C-7 & 1471 & $1853(0.38)$ & - & $\begin{array}{c}>2452(0.51), 21.5 \mathrm{hr}^{*} 4 \\
2175(0.45), 44 \text { days }\end{array}$ \\
\hline
\end{tabular}

* 1 . The values in parenthesis are the load level.

*2. For example, "180+47" means heating time is 180 minute, and the specimen collapsed at 47 minute after heating. "115" means a specimen collapsed during heating at 115 minute.

*3. The specimens were tested after the period described in the table. The period means the time passing after the fire test.

*4. Specimens A-3 and C-7 could not be collapsed by the apparatus initially foreseen and had to be tested by another apparatus later.

\section{THE SIMULATIONS.}

The tests have been simulated with the code SAFIR [3] and with the code Fires - Frame I $[4,5]$. Table 7 presents some differences concerning the calculation of temperatures inside the specimen. 
TABLE 7. Differences of temperature calculations for SAFIR and Fires - Frame I.

\begin{tabular}{|l|c|c|}
\hline Code & SAFIR & Fires - Frame I \\
\hline Formulation & Finite elements & Finite differences \\
\hline Evaporation & From 100 to $200^{\circ} \mathrm{C}$ & At $100^{\circ} \mathrm{C}$ \\
\hline $\begin{array}{l}\text { Material properties } \\
\text { during heating up }\end{array}$ & EC4 $[2]$ except ${ }^{*} 1$ & EC4 $[2]$ except ${ }^{*} 2$ \\
\hline $\begin{array}{l}\text { Thermal conductivity } \\
\text { during cooling down }\end{array}$ & $\begin{array}{l}\text { Value corresponding } \\
\text { to the maximum } \\
\text { temperature }\end{array}$ & Not accounted this time \\
\hline
\end{tabular}

${ }^{*}$ 1. Constant evaporation rate from $100^{\circ} \mathrm{C}$ to $200^{\circ} \mathrm{C}$ ( negligible effect ). The thermal conductivity of concrete is increased by $0.005 \mathrm{~W} / \mathrm{mK}$ for each $\mathrm{kg} / \mathrm{m}^{3}$ of moisture as suggested by [9].

*2. Thermal diffusivity reduced to about $70 \%$ of the original value of EC4.

The calculated temperatures are in good agreement with the experimental results, and were applied to the calculations of structural fire behaviour.

The structural behaviour of the tests have been simulated with the updated Schneider concrete model, as well as with the EC4 model [2] for concrete. The evolution of the concrete strength during cooling down is according to annexe $\mathrm{C}$ of [2]. The mechanical properties of reinforcing steel were taken from EC4 [2], considering that the strength recovers completely as the material cools down. The residual strength of columns was predicted by two approaches which were: 1) accumulation of residual strength calculated either with Eq. 17 proposed in $[10,11,12]$ or with the EC4 model as a function of the maximum experienced temperature, and 2) SAFIR either with the updated Schneider model or the EC4 model. In SAFIR, the specimens which exhibit no failure after $180 \mathrm{~min}$. are unloaded, allowed to cool down and reloaded.

$$
\begin{array}{ll}
\mathrm{f}_{\mathrm{r}}=\mathrm{f}_{\mathrm{C}} & \left(20<\mathrm{Tmax} \leq 200^{\circ} \mathrm{C}\right) \\
\mathrm{f}_{\mathrm{r}}=\mathrm{f}_{\mathrm{c}} \times\{1-(\mathrm{T}-200) / 600\} & \left(200<\operatorname{Tmax} \leq 500^{\circ} \mathrm{C}\right)
\end{array}
$$

$$
\begin{aligned}
& \text { where } f_{r} \quad: \quad \text { residual strength, } \\
& f_{C}: \text { concrete strength at room temperature, } \\
& \text { Tmax : } \quad \text { experienced maximum temperature. }
\end{aligned}
$$

\section{COMPARISONS.}

The deformation behaviour can be observed on Fig. 3. The numerical results by the two codes differ slightly even when the same material models are used. The differences beyond 180 minutes have been explained by the different ways of calculating temperatures. The differences before 180 minutes are limited and the general pattern of the curves obtained with the same material model are similar for the two programs. The general trend is that the EC4 model leads to larger elongations (test A-1 and B-1 to B-5) than the updated Schneider model. The latter is much closer to the experimental results than the EC4 model. 


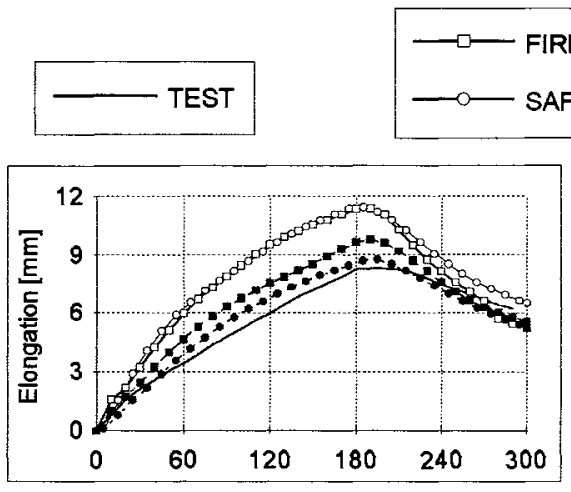

Test A-1

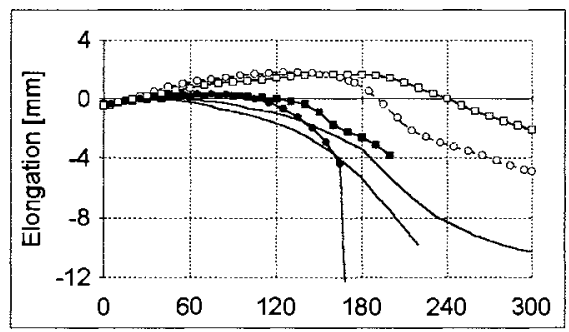

Tests B-3 and B-4



Test C-1

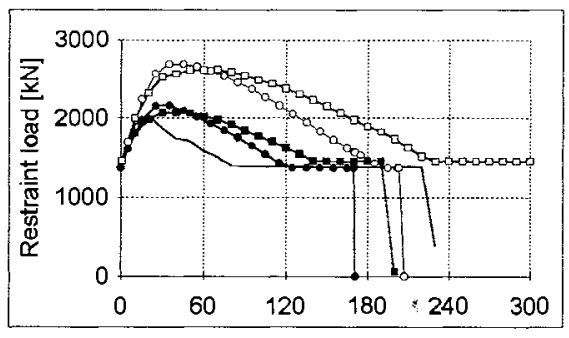

Test C-5



Tests B-1 and B-2



Test B-5

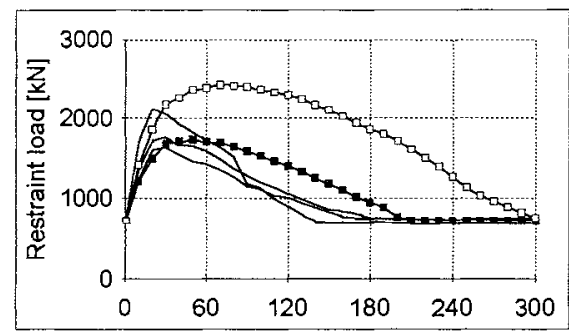

Tests C-2, C-3 and C-4



Test C-6

FIGURE 3. Comparison between numerical simulations and experimental tests. 
The comparisons of restraint forces ( test C-1 to C-6 ) lead to the observation that the EC4 model is by far to stiff, i. e. an overestimation of more than $50 \%$ of the measured loads may occur. The Schneider model is able to calculate the restraint within an acceptable range of deviation from the test results and is in so far superior. A modification of the EC4 model should be considered in the near future.

EC4 results presented on Fig. 3 have been obtained with the recommended values of [2]. Six tests have been recalculated by SAFIR with the moximum values of [2]. The results are located approximately half way between the EC4 and the SCH curves of Fig. 3.

The residual strength of columns are shown on Fig. 4. The residual strength calculated with the Schneider model - either by SAFIR or by an accumulation method and Eq. 17 - is mostly lower than the residual strength calculated with the EC4 model - by the both methods - . A part of it is due to the fact that Eq. 7 describing the evolution of strength is somewhat more severe than the corresponding equation in EC4. When compared to the experimental values, $50 \%$ of the results calculated with the proposed model compare better than the results calculated with the EC4 model, and $50 \%$ compare worse.

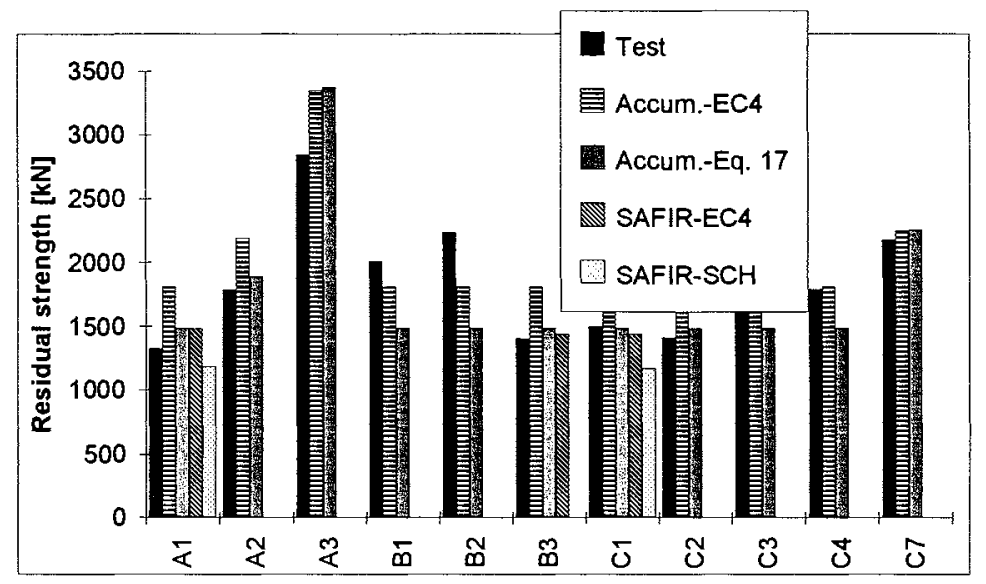

FIGURE 4. Residual strength.

\section{CONCLUSIONS.}

A new material model has been proposed for the uniaxial stress - strain relationships of concrete in compression at elevated temperature, which considers the influence of the load level during heating, the effect of creep on the stiffness of concrete and the plastic behaviour at high load level. Based on experimental tests made in Germany on normal concrete, the model, when implemented in two finite element analysis programs, proved to provide quite satisfactory results compared to the results of experimental tests which were independently performed in Japan. The proposed Schneider model tends to show less stiffness than the EC4 concrete model for the tested concrete ( $\mathrm{fc}=43 \mathrm{MPa}$ at 28 days, $59 \mathrm{MPa}$ at 90 days ). The EC4 model leads to higher residual strength than the proposed model does. 
The experimental results show that the compressive strength of reinforced concrete columns during fire is irrelevant to the restraint load. The residual strength is dependent on the load conditions during fire. The sustained load level of about 0.15 or more leads to a higher residual strength than the unloaded condition does.

\section{REFERENCES.}

1. Schneider, U., "Concrete at High Temperatures - A General Review", Fire Safety Journal, $13: 55-68,1988$.

2. Eurocode 4. Design of Composite Steel and Concrete Structures. Part 1.2. : Structural Fire Design.. CEN/TC250/SC4 N39, pr ENV 1994-1-2,.Second Draft 1992

3. Franssen, J.M., Schleich, J.B., Cajot, L.G., Talamona D., Zhao, B., Twilt, L. and Both, K., "A Comparison Between Five Structural Fire Codes Applied to Steel Elements" 4th Int. Symp. on Fire Safety Science, Ottawa, 1994.

4. Saito, H., Uesugi, H., Yamaguchi, M. and Kodaira, A. "Thermal Stress and Deformation of Steel Structures of High Rise Buildings in Fire", Fire Safety Science - Proc. of the 2nd Int. Symp., 719-728, 1989.

5. Morita, T., Uesugi, H., Wakamatsu, T. and Saito, H. "Analyses of Composite Beams and Frames at Elevated Temperature", Fire Safety Science - Proc. of the 3rd Int. Symp., 761$770,1991$.

6. Schneider, U., Properties of materials at high temperatures - Concrete, Department. of Civil Engineering, Kassel, 1985.

7. Schneider, U., Diederichs, U., Ehm, C.and Hinrichsmeyer, K., "Hochtemperaturverhalten von Festbeton", in Sonderforchunsbereicht 148. Brandverhalten von Bauteilen. Arbeitsbericht 1981 - 1983. Teil II, T.U. Braunschweig, 5-158, 1983.

8. Enforcement No.2999 of Ministry of Construction of Japan.

9. Naas Lien, H.P., Sadouki, H. and Wittmann, F.H., "Determination of the coupled heat and mass transfer in thick-walled concrete vessels", Proc. of the 3rd Int. Symp. Behaviour of Concrete Elements under Thermal and Hygral Gradients., Wiss. Z. Hochsch. Archit. Bauwes. Weimar, Heft 3./4./5, 161-164, 1992.

10.Morita, T., Saito, H. and Kumagai, H., "Residual Mechanical Properties of High Strength Concrete Members Exposed to High Temperature - Part 1. Test on Material Properties -", Summaries of Techn. Papers of Annual Meeting, Arch. Inst. of Japan, Niigata, Aug. 1992

11.Saito, H., Kumagai, H. and Morita, T., "Residual Mechanical Properties of High Strength Concrete Members Exposed to High Temperature - Part 2. Test on Reinforced Concrete Beams -", Summ. Techn. Papers Annual Meeting, Arch. Inst. of Japan, Niigata, Aug. 1992

12.Kumagai, H., Saito, H. and Morita, T., "Residual Mechanical Properties of High Strength Concrete Members Exposed to High Temperature - Part 3. Test on Reinforced Concrete Columns -", Summ. Techn. Papers Annual Meeting, Arch. Inst. of Japan, Niigata, Aug. 1992 